\title{
WHAT IS THE UK'S TRUE CONSTITUTION?
}

Ewan McGaughey*

\section{Abstract}

If the UK codified its constitution as it is now, not as one might like it, what would it say? In 2007 Professors Bogdanor, Vogenauer and Khaitan produced a remarkably clear and succinct model 'British constitution'. It reflected a set of values conventional for early $20^{\text {th }}$ century political theory: the monarchy, parliamentary procedure, law and order, and a list of rights based on a minimalist reading of the European Convention on Human Rights without much case law. It was unclear how these norms were arrived at, except that they were curiously similar to Bogdanor's own previous writings, particularly by elevating referendums to be a constitutional value. By contrast, this paper discusses what an evidence-based codification of our constitution would look like, grounded upon (1) people's social priorities and spending, (2) enduring Acts of Parliament, (3) consistent principles of case law. This suggests democracy, the rule of law, the social state, and international comity are core constitutional principles. An overlapping consensus in UK society sees far more rights as fundamental: rights to free public health, dignity in old age, universal education, social inclusion, fair taxation, protection for the environment and countryside, fair wages through voice at work, and transparent and accountable governance of finance and enterprise. This paper's central argument is that an ossified romanticism about supposed constitutional norms should not elevate, without evidence, the importance of some Acts of Parliament over others. The evidence shows the UK's true constitution is just.

\section{Contents}

\section{INTRODUCTION ... 1}

\section{What DOES 'CONSTitUTIONAL' LAW MEAN? ... 3}

(1) Expert deliberation ... $3 \sim$ (2) Conceptual distinction ... $4 \sim$ (3) Deliberative democracy ... 6

3. What DOES THE EVIDENCE SAY ABOUT OUR CONSTITUTION? ... 6

(1) Social priorities ... $6 \sim$ (2) Enduring Acts of Parliament ... $9 \sim$ (3) Principles in case law ... 14

$$
\text { 4. Conclusion ... } 17
$$

\section{INTRODUCTION}

If flexibility is a primary virtue of the UK's uncodified constitution, it is equally matched by opacity. Without any code to delineate what is in and what is out, the 'constitution' is often said to be everything that 'constitutes' the body politic, ${ }^{1}$ or that the constitution is just 'what happens'. ${ }^{2}$ This is partly justified if, like Blackstone, we see constitutional law as one branch of the law of persons. ${ }^{3}$ A nation-state is like any other organic, social institution, where its members experience life both as part of the community and as individuals, 'intertwined in reality as an indissoluble unity... distinct only in our imaginations. ${ }^{34}$ Similarly, among many, many foundational contributions to our understanding of justice that Professor Keith Ewing has made, there is a recurring theme: a constitution that locks up gates at Downing Street, blockades Whitehall, or kettles Parliament Square, away from the wider world is weaker. Dividing civil and

\footnotetext{
Senior Lecturer, School of Law, King's College, London. Research Associate, Centre for Business Research, University of Cambridge. I am very grateful to Tarunabh Khaitan, Robert Craig, Vernon Bogdanor and Alan Bogg for discussion and comments. Please contact at ewan.mcgaughey@kcl.ac.uk or @ewanmcg for deliberative discourse at any time.

cf W Bagehot, The English Constitution (1894)

JAG Griffith, 'The political constitution' (1979) 42(1) Modern Law Review 1, 19

W Blackstone, Commentaries on the Laws of England (1753) Book I

O Gierke, 'The Social Role of Private Law' (1889) translated by E McGaughey (2018) 19(4) German Law Journal 1017
} 
political freedom from economic, social and cultural rights enables state power to cultivate private oppression. Law constructs power, public or private, with property, contract, or any form of regulation. ${ }^{5}$ Our economic constitution shapes our politics (not least in the freedom that unions, ${ }^{6}$ or political parties, have to influence the law) just as politics shapes our economy. This tradition of thought sees that, unless our social constitution is perceived as a whole, people in the supposed private sphere are left 'practically at the mercy of corporations and individuals wielding power under public authority. ${ }^{8}$

But without a codified document, how do we begin to answer 'what is the UK's true constitution?' One answer was given in a 2007 article by Professors Bogdanor, Vogenauer, and Khaitan, assisted by a group of politics students. ' They drafted a UK constitution, claiming it to be 'as it actually is rather than as it might be or as it ought to be.' An admirably clear document of just eleven pages, their method drew on statute and personal understandings of a constitution's proper limits. It starts with territory and nationality, with the monarch as a sovereign. ${ }^{10}$ Then come the Commons and the Lords,${ }^{11}$ the Prime Minister, executive power, ${ }^{12}$ local government,${ }^{13}$ judicial review,${ }^{14}$ and last a human rights list that reflects a minimal reading of the European Convention on Human Rights, ${ }^{15}$ without much case law. It also raises the idea of referenda for transfers of power to a constitutional principle. ${ }^{16}$ The trouble is, it is doubtful that this is the UK constitution 'as it actually is'. Instead, it was curiously similar to previous writings by Professor Bogdanor, particularly by elevating referendums to a supposed constitutional norm. Many of these arguments, particularly with the unprecedented 'Brexit' poll crisis, do not look great today. ${ }^{17}$

This chapter's purpose is to ask, what would an evidence-based understanding of our constitution lead to? Its central argument is that it is impossible to justify a document asserting itself as the UK's true constitution without a reasoned and evidential basis. Logically, evidence should include what government does, people's real social priorities, an historically informed account of enduring Acts of Parliament, and

KD Ewing, 'The State and Industrial Relations: 'Collective Laissez-Faire' Revisited' (1998) 5 Historical Studies in Industrial Relations $1,2-3$ and 31

e.g. KD Ewing and P Elias, Trade Union Democracy, Members' Rights and the Law (1987)

e.g. KD Ewing, The Cost of Democracy: Party Funding in Modern British Politics (2007)

Civil Rights Cases, 109 US 3 (1883) per Harlan J and cf KD Ewing (2017) 28(2) King's Law Journal 343, 361, 'democracy is about the equal participation of citizens (with all that that implies) and their representative institutions in making and administering the rules by which they are governed. This includes the rules made not only by those exercising public power, but also by those exercising private power as well.'

V Bogdanor, T Khaitan and S Vogenauer, 'Should Britain have a written constitution?' (2007) 78(4) Political Quarterly 499

Bogdanor et al (2007) arts 1-4

Bogdanor et al (2007) arts 5-11

Bogdanor et al (2007) arts 12-22

Bogdanor et al (2007) arts 23-25

Bogdanor et al (2007) arts 26-35

Bogdanor et al (2007) arts 36-58

Bogdanor et al (2007) arts 1, 23 and 59(2)

e.g. V Bogdanor, The people and the party system: The referendum and electoral reform in British politics (1981), V Bogdanor, 'Referendums in British politics' (1988) 2(4) Contemporary Record 12, D Butler and A Ranney (eds), Referendums around the world: The growing use of direct democracy (1994) ch 3. Professor Bogdanor tutored David Cameron, who staged three referendums, but said before Cameron seized the keys to number 10, 'David was one of the nicest and ablest students I ever taught. But I'm not responsible for his views.' C Arnot, 'Interview: Ruling Class' (17 February 2009) Guardian. On consequences of referenda used as a political instrument, see E McGaughey, 'Could Brexit be Void?' (2018) 29(3) King's Law Journal 331, and AJ Zurchner, 'The Hitler Referenda' (1935) 29(1) American Political Science Review 91, on crude, familiar strategies. See also C Sunstein, Designing Democracy: What Constitutions Do (2001) 7, 'Deliberative democrats emphatically reject the view that a government should be run on the basis of popular referenda.' 
of consistent principles in case law. It argues that Parliamentary democracy, the rule of law, the social state, and international comity, are essential principles of the modern UK constitution. An overlapping consensus in UK society recognises that constitutional rights include free public health, dignity in old age, universal education, social inclusion, fair taxation, protection for the environment and countryside, fair wages through voice at work, and transparent and accountable governance of finance and enterprise. Many further additions could be debated. But whatever one favours as a preferred list of constitutional norms and rights, an account of what our constitution 'is' must not elevate, without evidence, the importance of some Acts of Parliament over others.

\section{What Does ‘CONSTITUTIONAL' LAW MEAN?}

Before examining what the evidence suggests about the UK's true constitution, it seems necessary to address a prior conceptual question: what does 'constitutional' law mean? To explain the constitution 'as it actually is rather than as it might be or as it ought to be', there are a range of alternative methods, with differing strengths and weaknesses. Three main alternatives are (1) for experts to deliberate, (2) to conceptually distinguish 'constitutional' law based on a public/private law divide, and (3) to follow deliberative democratic debate, and do so without limit.

\section{(1) EXPERT DELIBERATION}

A first alternative is to construct a constitution based upon expert deliberation. This fits closely with the methodology of Professors Bogdanor, Vogenauer and Khaitan, as they 'held a seminar at Oxford, at which students were asked to draft a constitution for Britain'. ${ }^{18}$ This produced an exceptionally clear document. ${ }^{19}$ Yet it is curious that what were said to be the 'many areas of unclarity' about our constitution appeared resolved without appeal to any external sources. The authors were quick to concede that it is impossible to say whether the students' answers accurately reflected the present state of the constitution precisely because nobody knows what the constitutional position actually is.' However, this concession appeared mostly to relate to a small number of grey areas, with 'insufficient clarity', rather than their constitution's broad shape. To demarcate that broad shape a criterion of 'controversiality' was applied for what was in or out, so that if someone argued that a norm belonged to the realm of political debate, it would not be included: that became what the constitution 'might be' or 'ought to be', not what it was. As a result, the Appendix was proclaimed as 'The Constitution of the United Kingdom, as of 1 January 2007'.

The central difficulty of this method is the absence of a documented process of reasoning. Because no reasoning can be discerned, any product becomes an appeal to authority, saying 'it is constitutional because I think it is'. ${ }^{20}$ A criterion of excluding norms as 'constitutional' if they are

\footnotetext{
18 Bogdanor et al (2007) 78(4) Political Quarterly 499.

19 Significant credit - although certainly a shared project - was attributed in the drafting to Tarunabh Khaitan. But it appears that certain values, such as the constitutional importance of equality, were not accorded sufficient weight in the final draft. On the values of anti-discrimination law, see the pathbreaking work, T Khaitan, A Theory of Discrimination Law (2015).

20 Contrast A Schopenhauer, Die Kunst, Recht zu Behalten (1831) \#30 on appeal to authority, rather than reason.
} 
controversial in a select group fails to see that the norms of most constitutions (successful or not) emerge precisely after the settlement of controversies, and indeed bitter conflict, revolution, collapse, crisis, dictatorship, or war, ${ }^{21}$ including the constitution of international law, and the 'Magna Carta of all' people, itself. $^{22}$ Moreover, a controversiality threshold is likely to be illegitimately minimalist, if not reactionary, in much the same way that an overlapping agreement between Dicey, Raz and Dworkin on the meaning of the 'rule of law' would probably produce the barest bones of 'legality', ${ }^{23}$ rather than include respect for international law and human rights. ${ }^{24}$ Private expert deliberation cannot credibly establish what is 'constitutional' law and what is not, without disclosing reason and evidence.

\section{(2) Conceptual Distinction}

A second alternative is to defend a conceptual distinction of 'constitutional' law based upon a public/private divide, or something related to it. The existence of equity, and British scholars' aversion to theory, means the notions of public and private law are not part of UK legal tradition. ${ }^{25}$ Yet the divide has increasingly become popular for the purpose of demarcating time limits and the proper forum for judicial review, ${ }^{26}$ the organisation of textbooks, ${ }^{27}$ even some academic titles. ${ }^{28}$ Going further back, it was a basis for arranging competence between the union and Scottish legal systems, ${ }^{29}$ and it has also long been common to speak of the 'constitution' as 'directed to certain fix'd Objects of publick Good' and how 'the Community hath agreed to be governed' ${ }^{30}$ This continues in a general view that the constitution relates to the 'basic institutions of the state' and the relation of these to 'the individual'. ${ }^{31}$ In European Union law the same idea of 'vertical direct effect' as opposed to 'horizontal' application of rights was introduced by British advocates. ${ }^{32}$ On this view, to be constitutional, 'power-conferring' rules must be no more than one degree of separation from Parliament Square. ${ }^{33}$ Constitutional law is 'public law' minus administrative and criminal law, while private law covers the law of persons, property and obligations. The lines may be 'blurry and wobbly', ${ }^{34}$ but the distinction can be kept on track, by saying that all 'contextual' subjects that do not fit (like cyberspace law or labour law) are a mixture of public and private law. ${ }^{35}$

\footnotetext{
21 This is true, for example, of the United States (post-Revolution), India (post-Independence), Germany (post-WW2), France (post-Revolution, Napoleon, WW2, etc), China (post-Mao under Deng Xiaoping), Brazil (post-dictatorship), Russia (post-Iron Curtain), South Africa (post-Apartheid), and the United Kingdom for large part of its own constitution (the Magna Carta, Bill of Rights, etc). These examples alone account for all of the UN Security Council, and about half the globe's population.

22 See the United Nations Charter 1945 and the Universal Declaration of Human Rights 1948.

23 cf AV Dicey, Introduction to the Study of the Law of the Constitution (3rd edn 1889) Part II, ch IV, 189, J Raz, 'The Rule of Law and its Virtue' (1977) 93 Law Quarterly Review 195. R Dworkin, A Matter of Principle (1985) 32.

24 cf T Bingham, 'The Rule of Law' (2007) 66(1) Cambridge Law Journal 67 and see also T Bingham, Rule of Law (2008) 8.

25 cf AW Bradley, KD Ewing and CJS Knight, Constitutional and Administrative Law (2018) 677, 'O'Reilly relied heavily on the public law/private law distinction, despite the difficulties that this presents in English law.'

O’Reilly v Mackman [1983] 2 AC 237, 255 per Lord Denning MR.

e.g. A Burrows (ed), English Private Law (2017) and D Feldman, English Public Law (2017)

The author was originally hired as a 'lecturer in private law', teaching one notable subject with a 'professor of public law'.

Union with Scotland Act 1706 art 18

Viscount Bolingbroke, A Dissertation upon Parties (1733) Letter X, 108.

HL Committee on the Constitution (HL Paper 11, 2001-2) ch 2.

e.g. Marshall v Southampton and South West Hampshire Area Health Authority (1986) Case 152/84, [1986] ECR 723.

cf HLA Hart, The Concept of Law (1961) ch 5(3) on secondary rules, which recognise, change or adjudicate rule making power.

See e.g. D Feldman and M Elliot, The Cambridge Companion to Public Law (2018) ch 1.

cf FH Easterbrook, 'Cyberspace and the Law of the Horse' [1996] University of Chicago Legal Forum 207, 208.
} 
The difficulty with this view is that the public/private divide is philosophically empty, and it has long been constitutionally abused. Philosophically, the most robust defence for a public/private divide seems to be that it is a 'conceptual' distinction, not a 'contextual' one. ${ }^{36}$ The trouble is, the state itself is a contextual creature. It is one legal person among many, and remains so even when public/private advocates relegate the other persons to 'private' law. ${ }^{37}$ It is naive to think the state pursues more 'public' purposes than companies or families, because (even ignoring cases where companies and families dominate states) historically this is just not true. ${ }^{38}$ It might be argued that the state has a 'distinctive claim to the legitimate exercise of coercive force..$^{39}$ But since 1919, international law and human rights have delegitimised that very exercise of coercive force by states over people, ${ }^{40}$ and democracy emerged to replace coercive force with electoral consent, as violence became less legitimate in any case. ${ }^{41}$

Constitutionally, the public/private divide has routinely been abused. For instance, it was said in the US Civil rights cases that state 'intervention' in private property (an ostensibly pre-state thing) to protect ex-slaves from discrimination was unconstitutional. ${ }^{42}$ In Locbner $v$ New York, the US Supreme Court went further to strike down state 'interference' in private freedom of contract, which included a limit to a 60 hour week for bakes. ${ }^{43}$ What followed were decisions striking down public pensions, ${ }^{44}$ minimum wages, ${ }^{45}$ union organising, ${ }^{46}$ and even a ban on child labour. ${ }^{47}$ This was wrong, and the better view was always that all law is social, not public or private, and no division between the two can justify normative consequences. The better view is that the 'concept of all law's unity' must be defended. ${ }^{48}$ There is no conceptual reason why inter-individual or horizontal rights may not be constitutional issues, or even at the centre. All individual rights must ultimately reflect the public good, and the state must serve individual freedom. ${ }^{49}$

\section{(3) Deliberative Democracy}

A third alternative is to say that what is 'constitutional' law depends upon the outcome of ongoing deliberative discourse. Putting a reflective equilibrium into real life, ${ }^{50}$ 'constitutional' can mean anything

P Birks, Introduction to the Law of Restitution (1984) 73

W Blackstone, Commentaries on the Laws of England (1753) Book I

38 e.g. T Paine, Rights of Man (1791) part I, the 'national purse is the common hack which each [party insider] mounts upon'. cf Feldman and Elliot (2018) ch 1, conclusion.

39 Feldman and Elliot (2018) ch 1, an idea taken from the pre-modern distinction of M Weber, Politik als Beruf (1919).

40 e.g. UN Charter 1945 art 2(4) and Universal Declaration of Human Rights 1948 arts 3-5, which limit state powers of coercion. This means that international law, not solely the state, determines legitimate exercise of force, and justifiably claims to do so.

41 Recently in the UK, see A Ashworth, 'What if imprisonment were abolished for property offences?' (2013) Howard League.

42 United States $v$ Stanley 109 US 3 (1883)

43 Lochner v New York 198 US 45, 64 (1908)

44 eg State Board of Control v Buckstegge, 158 Pac 837, 842 (1916)

45 eg Adkins v Children's Hospital, 261 US 525 (1923)

${ }^{46}$ eg Coppage v Kansas, 236 US 1 (1915) and Duplex Printing Press Co v Deering, 254 U.S. 443 (1921)

47 eg Hammer v Dagenhart, 247 US 251 (1918) and Bailey v Drexel Furniture Co, 259 US 20 (1922)

48 O von Gierke, The Social Role of Private Law (1889) translated with an introduction by E McGaughey (2018) 19(4) German Law Journal 1017, 1037-8.

49 eg Universal Declaration of Human Rights 1948, Preamble: 'recognition of the inherent dignity and of the equal and inalienable rights of all members of the human family is the foundation of freedom, justice and peace in the world'

50 cf J Rawls, A Theory of Justice (1971) ch 1 
that emerges from the 'laboratories of democracy' - polities of all kinds - at any given moment in history. ${ }^{51}$ As Frederic Maitland said, we must 'not get into the way of thinking of law as consisting of a number of independent compartments, one of which is labelled constitutional, another administrative, another criminal, another property... law is a body, a living body, every member of which is connected with and depends upon every other member. ${ }^{52}$ Historically, there is 'hardly any department of law which does not, at one time or another, become of constitutional importance'. ${ }^{53}$ This simple truth, once acknowledged, liberates the constitutional mind, and so it is to this conception that we now turn.

\section{WHAT DOES THE EVIDENCE SAY ABOUT OUR CONSTITUTION?}

To understand the UK constitution as it is today, it seems logical to look at evidence about what the different branches of government and the state do and say. The three main branches of government are, of course, the executive, legislature and judiciary. Each provide a wealth of data - financial, historical, jurisprudential - on the nature of the UK constitution. If we are to codify the UK constitution as it 'is', it makes sense to start with these.

\section{(1) SOCIAL PRIORITIES AND SPENDING}

A starting guide to the UK's constitution is found in what the UK state actually spends most time doing. From the annual budgets it is clear what the preoccupations of modern UK society, and the state, are. According to the Autumn budget of 2018, 60.5 per cent of government spending is taken up by social security, social care and health spending. ${ }^{54}$ Education is 13.7 per cent of spending. Defence and public order are 11.5 per cent of spending. Debt interest (mostly paying money to banks) is 5.7 per cent, transport 4.9 per cent, industrial, agricultural and employment policy 3.3 per cent, and so on.

Almost none of these fields of spending - almost all of what government actually does, almost all of what (in the time before the 'Brexit' poll) preoccupies politics - is reflected in the Bogdanor constitution. Passing mention was given to a minimal right that 'No person shall be denied the right to education' or 'a minimum right of health care and subsistence. ${ }^{55}$ The only people who appear to retire in this constitution are judges, the Speaker of the Commons and the Lords, and even then it seems only judges get a pension. ${ }^{56}$ Speaker retirement and judicial pensions are important norms. But when nearly one-third of all UK government revenue is directed at retirement pensions for the general public, it would seem difficult to maintain that the right to social security is not an important constitutional norm.

\footnotetext{
51 New State Ice Co v Liebmann 285 US 262 (1932) per Brandeis J

52 FW Maitland, The Constitutional History of England (1919) Period V, J, 538-9 and cf AW Bradley and KD Ewing, Constitutional and Administrative Law (2018) ch 21, 591-2, on the 'deceptively simple' public and private law distinction.

Maitland (1919) Period V.J. 538

HM Treasury, Autumn Budget (October 2018) 4

Bogdanor et al (2007) 78(4) Political Quarterly 499, 516, arts 53 and 56

Bogdanor et al (2007) 78(4) Political Quarterly 499, 507-8 and 513, arts 6, 8 and 34-35
} 


\section{Public sector spending ( $\mathrm{fbn}$ ) 2019-2020}
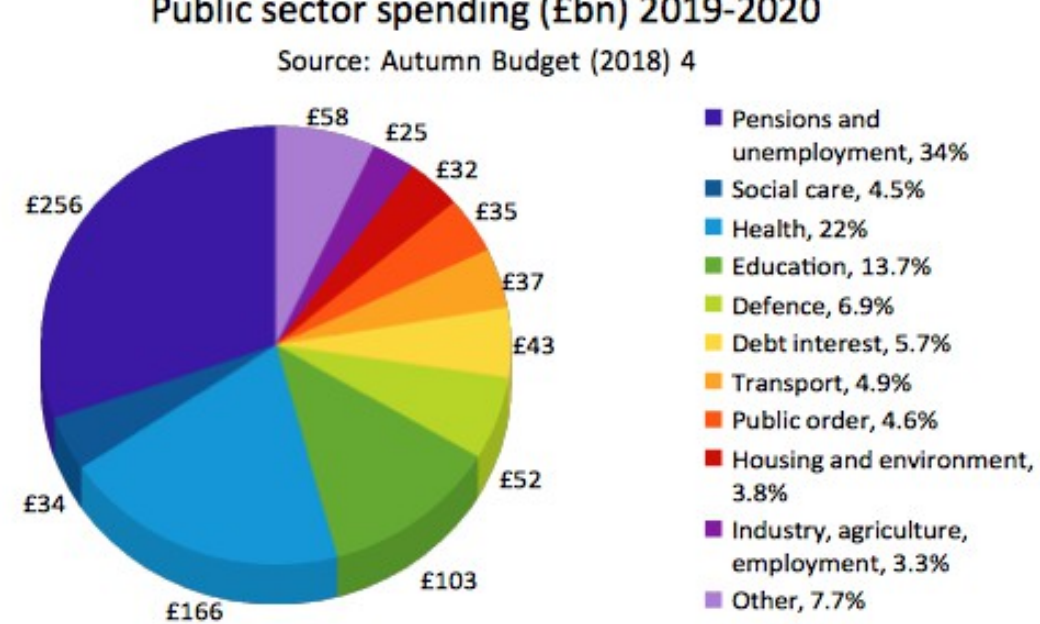

All fields of significant spending developed in response to the most important constitutional conflicts in modern UK history. First, the principles for the state pension and unemployment insurance are found in the Social Security Contributions and Benefits Act 1992. ${ }^{57}$ This codifies the National Insurance system first set up through the Old-Age Pensions Act 1908 and the National Insurance Act 1911. There can be no doubt that the People's Budget, which also led to the Parliament Act 1911, was a constitutional crisis of a fundamental kind, resolved through Lloyd George threatening to pack the House of Lords, and the persuasion of the King to back His Majesty's government against the aristocracy. ${ }^{58}$ The right to social security was therefore inextricably linked to the development of representative government.

Second, health and social care, 26.5 per cent of UK spending, developed through the National Health Service Act 1946, today found in the National Health Service Act 2006. The NHS is not (as the Bogdanor constitution says is enough) a 'minimum right of health care and subsistence'. The NHS is a comprehensive, public service, free at the point of use. ${ }^{59}$ It resulted from the Beveridge Report's determination to eradicate disease, alongside the welfare system's fight against want, squalor, idleness and ignorance. ${ }^{60}$ Even critics of universal, public health care accept that the NHS is 'the closest thing the English people have now to a religion'. ${ }^{61}$ It has become a political consensus, which hostile parties only question through guarded, surreptitious, or even covert remarks that are later qualified or denied. ${ }^{62}$ It therefore seems prudent to suggest that free, public health care has constitutional value.

Third, education spending, particularly on schools, is structured by the School Standards and Framework Act 1998, tracing back to the Elementary Education Act 1870. The development of the

${ }^{57}$ Also the Jobseeker's Act 1995, and multiple revisions.

58 MR Cohen, 'Property and Sovereignty' (1927) 13 Cornell LQ 8, 43, 'That which was hidden from Maitland, Joshua Williams, and the other great ones, was revealed to a Welsh solicitor who in the budget of 1910 proposed to tax the land so as to force it on the market....'

59 Department of Health, NHS Constitution for England (27 July 2015) arts 1(2) 'Access to NHS services is based on clinical need, not an individual's ability to pay....'

60 W Beveridge, Social insurance and allied services (1942) $\mathrm{Cmd} 6404$

61 N Lawson, The View from No. 11: Memoirs of a Tory Radical (Bantam 1992) 613

62 R Mason, 'Film shows Nigel Farage calling for move away from state-funded NHS' (12 November 2014) Guardian, a spokesperson saying for Farage, 'That was then and this is now. It doesn't stand up to say that's still his view.' 
school system was also intimately intertwined with UK constitutional development. The Second Reform Act 1867, which extended the right to vote to more working class people, was bitterly opposed by the then editor of The Times, Robert Lowe, a Liberal MP. Though Lowe lost the fight, he beat Walter Bagehot to be MP for the University of London, and became Chancellor of the Exchequer under Gladstone. Seeing he would be defeated in stopping the franchise extension, Lowe urged that because workers would have the vote, Parliament had to 'educate our masters'. ${ }^{63}$ Like pensions and health, universal free education was one of the most significant constitutional developments in modern UK history.

Similar stories can be told for all fields of spending. The importance of national security and public order, ${ }^{64}$ which cannot be understated, comes from the experience of revolution and war. The duty of the state to manage debt by providing financial stability, create employment, and control inflation, ${ }^{65}$ comes from a long history, dating back to the contest between the Bank of England and the South Sea Company to be the banker of a fledgling united Britain. The collapse of the South Sea Company, which took on the national debt, led to the world's first stock market crash, ${ }^{66}$ the incarceration of the Chancellor of the Exchequer in the Tower of London, and the development of the office of Prime Minister through the Tory party's disgrace for a generation. ${ }^{67}$ The rights to housing, accommodation, and a clean, safe, environment, ${ }^{68}$ were essential to the welfare state's development, and public health, which all democratic movements fought for. Transport policy, and the right to services of general economic interest, ${ }^{69}$ were not only essential to industrialisation and economic development, but at the centre of experiment with models of nationalisation, privatisation and socialisation of the means of production. ${ }^{70}$

That the UK's true constitution is shaped by delivering better living standards (not just the power struggles between $17^{\text {th }}$ century offices of state) is reflected in consistent public opinion. ${ }^{71}$ Most notably, according to a 2006 survey of 2,231 people by ICM Research for the Joseph Rowntree foundation, 88 per cent thought the right to NHS treatment in a reasonable time should be included in any British Bill of Rights, just behind the right to a fair trial $(89 \%)$ and even ahead of the right to privacy $(82 \%)$, and freedom of assembly $(73 \%){ }^{72}$ The right to be housed was supported by $62 \%$ of conservative voters, and $65 \%$ of people overall. Testament to the fact that most people do not distinguish the constitution of politics and the economy, 77 per cent of people thought the right to strike, and to be protected against unfair dismissal for it, is a fundamental right, as indeed it is in law. ${ }^{73}$ Taken together, the evidence of

\footnotetext{
63 See previously, in opposing the Second Reform Act, 'You must take education up the very first question, and you must press it on without delay for the peace of the country.' Hansard HC Debs (15 July 1867) cols 1549-1550.

${ }^{64}$ See the Reserve Forces Act 1996, Armed Forces Act 2006 and the Police Act 1996.

65 See the Bank of England Act 1998.

66 e.g. W Blackstone, Commentaries (1753) Book IV, 117, referring to 'South-Sea project [that] had beggared half the nation'. A Smith, The Wealth of Nations (1776) Book V, ch 1, \$119

67 See J Carswell, The South Sea Bubble (1960) and R Dale, The First Crash: Lessons from the South Sea Bubble (2004)

68 e.g. Housing Act 1996, Environmental Protection Act 1990 and the Climate Change Act 2008.

e.g. Railways Act 1993, Highways Act 1980, and Greater London Authority Act 1999 ss 141-188 and Sch 10.

70 e.g. H Morrison, Socialisation and Transport: Organisation of socialised industries with the particular reference to the London passenger transport bill (1933)

71 See also Ministry of Justice, Rights and Responsibilities: Developing our Constitutional Framework (2009) Cm 7577, para 1.11, suggesting the NHS is a constitutional 'landmark' like the Magna Carta.

72 ICM, State of the Nation 2006: Summary Results (2006) question 15a.

73 See Wilson v United Kingdom [2002] ECHR 552 and Enerji Yapi-Yol Sen v Turkey [2009] ECHR 2251.
} 
people's social priorities through government spending and through dominant social opinion, suggests economic and social rights are at the core of the UK's true constitution.

\section{(2) Enduring Acts of Parliament}

A second main source of evidence about the UK constitution's true nature must be what the legislature does. Social spending makes clear that the principles underpinning the welfare state and public services have been consistently reproduced through major Acts of Parliament. Yet the list of enduring Acts - and Acts that have been consistently recast and recodified - goes much further. Law constructs our most important economic and social institutions, in labour, capital, markets and land. Consistent empirical evidence shows law must do so on a lasting and stable basis to protect and advance human development. ${ }^{74}$

It is now generally accepted that some Acts have greater constitutional significance than others, but this leaves the difficulty of determining which should be which and why. In R (HS2 Action Alliance Ltd) v Secretary of State for Transport, Lord Neuberger and Lord Mance (with the whole house agreeing) posited that despite our constitution being uncodified, we did have 'constitutional instruments' ${ }^{75}$

They include Magna Carta, the Petition of Right 1628, the Bill of Rights and (in Scotland) the Claim of Rights Act 1689, the Act of Settlement 1701 and the Act of Union 1707. The European Communities Act 1972, the Human Rights Act 1998 and the Constitutional Reform Act 2005 may now be added to this list. The common law itself also recognises certain principles as fundamental to the rule of law.

The Supreme Court went on to say that, it was 'certainly arguable' that 'fundamental principles' would not be construed as being abrogated by the UK's enactment of legislation to join international organisations. ${ }^{76}$ The Supreme Court's list was hardly exhaustive. It did not mention, for example, the United Nations Act 1946, which is unquestionably fundamental to the UK's place in the post-war international order, as both a member of the UN General Assembly (which first met in London), and a permanent member of the UN Security Council. The Supreme Court's point seems to be that while the UK enhances its sovereignty in global affairs by joining international organisations (like the UN, World Trade Organisation, and the European Union) it must do so based on the principles of democracy and human rights embedded in our constitution. ${ }^{77}$

\footnotetext{
4 e.g. S Djankov, C McLiesh and R Ramalho, 'Regulation and Growth' (2006) 92(3) Economics Letters 395, and RE Hall and CI Jones, 'Why do some countries produce so much more output per worker than others?' (1999) 114(1) Quarterly Journal of Economics 83. There remains, however, some, albeit diminishing disagreement about the types of regulation that serve capital formation, economic and human development. See S Deakin, 'The contribution of labour law to economic development and growth' (2016) Cambridge CBR WP 478.

${ }^{75}$ R (HS2 Action Alliance Ltd) v Secretary of State for Transport [2014] UKSC 3, [207]. Their Lordships adopted the colloquial expression 'unwritten constitution', though the constitution is written in statutes, caselaw and texts that describe conventions.

76 [2014] UKSC 3, [207]. On the facts, this meant that the requirements of the Environmental Impact Assessment Directive 2011 of public participation in planning decisions could not question internal Parliamentary procedure, and particularly a whipped vote to approve a high speed railway.

77 This is a similar argument to that used by the German Federal Constitutional Court in the Solange judgments: see Internationale
} 
But on the Supreme Court's list alone, many rules and principles were entirely ignored by the Bogdanor version of the UK constitution. For instance, the Magna Carta set out, not just rights to a fair trial, Parliament, and principles for taxation, but also rights to share in common land and resources. ${ }^{78}$ These rights to 'the commons' remained among the most important institutions through revolt and reformation, ${ }^{79}$ and composed a whole body of jurisprudence up to Sir Edward Coke's time. The commons was a key to welfare, until (through the era of enclosure) it was transformed into institutions such as the poor law, and ultimately the welfare state. ${ }^{80}$ The European Communities Act 1972, through its incorporation of the Treaty of Rome, did not just mean joining a supranational legislative structure, but made gender equality a general principle of law, even ahead of our own equal pay and sex discrimination legislation. ${ }^{81}$ The Human Rights Act 1998, incorporating the European Convention on Human Rights, did not just entail civil and political rights, but because it is a living document, it is now clearly seen to contain the right to collectively bargain and to take collective action. ${ }^{82}$ This is ultimately what guarantees, in the language of the Universal Declaration of Human Rights, the right to 'just and favourable remuneration'. ${ }^{83}$ In eloquent reflection, in the International Covenant on Civil and Political Rights and the International Covenant on Economic, Social and Cultural Rights, the only three rights repeated in each document are the rights to 'freely dispose of their natural wealth and resources', to be free from discrimination, and the right of people 'to form and join trade unions for the protection of [their] interests'. ${ }^{84}$

The problem of which Acts are more constitutional than others can logically be resolved by analogy to constitutional conventions: if Acts consistently retain certain norms in substance, this founds a case for those principles to be regarded as constitutional. For example, the Magna Carta and the Bill of Rights demonstrate how the right to a just system of taxation, based upon representative consent (the basis for a fair distribution of income and wealth) has endured: no tax without Parliament. ${ }^{85}$ The source of tax also highlights the UK's most important institutions that are constructed by legislation: that is the regulation of labour, capital, markets, land and the environment.

Within the tax base the Autumn Budget of 2018, first, projected that 41.3 per cent of revenue to be derived either from income tax, or national insurance: that is labour and capital income. Second, corporation tax stood at (after significant cuts) 7.4 per cent of revenue. Third, value added tax and excise

Handelsgesellschaft mbH $v$ Einfuhr- und Vorratsstelle für Getreide und Futtermittel [1974] 2 CMLR 540, 549 and Re Wünsche Handelsgesellschaft [1987] 3 CMLR 225.

78 Magna Carta 1215 clauses 44-48. This was then transferred in to the Charter of the Forest 1217, especially cl 9-12, signed at St Paul's in London on 6 November.

79 See J Froissart, Froissart's Chronicles (1385) translated by GC Macaulay (1895) 251-252, on the Peasants' Revolt, and T More, Utopia (1516) Book I, translated by P Turner (Penguin 2004) on sheep and enclosure.

80 See S Deakin and F Wilkinson, The Law of the Labour Market (2005) chs 2 and 3.

81 TFEU art 157(1) and Defrenne v Sabena (No 2) (1976) Case 43/75, [10] 'this provision forms part of the social objectives of the community, which is not merely an economic union, but is at the same time intended, by common action, to ensure social progress and seek the constant improvement of the living and working conditions of their people'. The Equal Pay Act 1970, despite the year of its enactment, only took effect as the Sex Discrimination Act 1975 was passed.

82 See Enerii Yapi-Yol Sen v Turkey [2009] ECHR 2251

83 UDHR 1948 art 23(3)

84 International Covenant on Civil and Political Rights 1966 arts 1,22 and 26, International Covenant on Economic, Social and Cultural Rights 1966 arts 1,2 and 8.

85 Magna Carta $1215 \mathrm{cl} 12$ and Bill of Rights 1689 art 4. The right to representation is in itself is some guarantee of fairness, even if the principle of progressive taxation has wild loopholes. 
duties - taxes on market transactions - were 25.3 per cent. Fourth, business rates and council tax - taxes on land - would generate 8.2 per cent of revenue. Under 'other taxes' are a growing number of environmental levies. Each tax base depends on the existence of stable legal institutions. Just like oppressive taxation before 1215 and 1688 led to constitutional revolutions, the stability of income and wealth distribution depends upon the stability of social institutions behind them, and the enduring patterns legislation that underpin them.

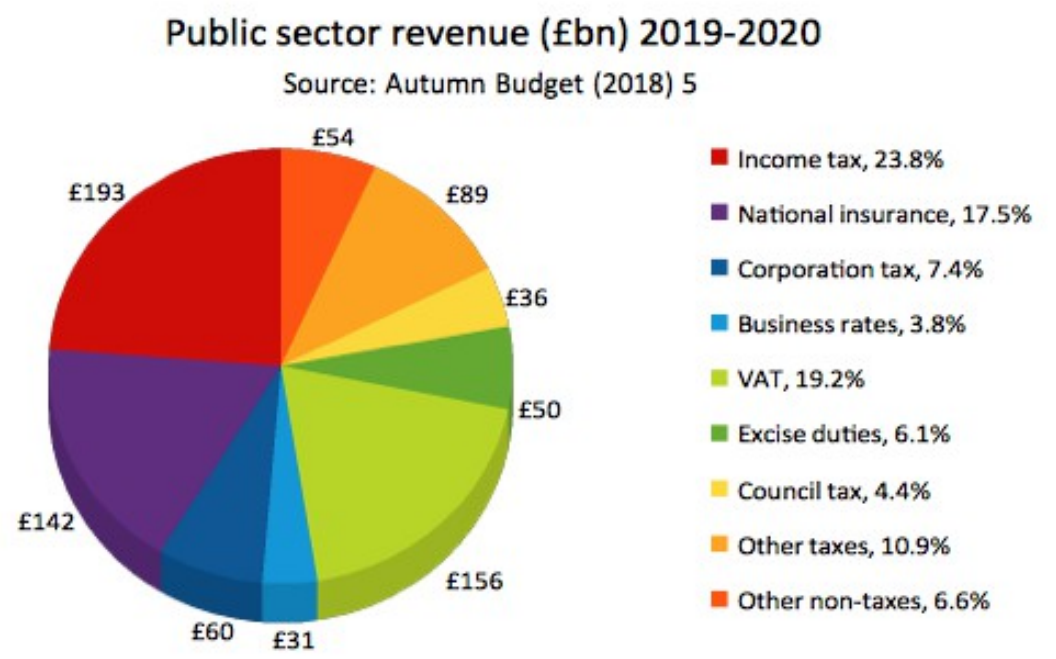

So first, what determines the structure of labour regulation? Four central statutes are the Employment Rights Act 1996, the National Minimum Wage Act 1998, the Trade Union and Labour Relations (Consolidation) Act 1992, and the Equality Act 2010. With many other norms, ${ }^{86}$ these function like 'a charter protecting employees' rights' ${ }^{87}$ The principles, frequently the same words, go back to the Trade Disputes Act 1906, the Trade Boards Act 1909, and the race relations and sex discrimination legislation of the 1960s and 1970s. Over successive, even bewildering revisions, ${ }^{88}$ even over intense political dispute, modern labour law has always advanced two principles. ${ }^{89}$ First, it guarantees a minimum floor of rights through which nobody must fall. Second, to get fair wages and conditions beyond the minimum, it guarantees voice at work, through collective bargaining and direct voting rights. The balance of power has shifted forwards and back, but the principles of labour law have never been substantively questioned, because they are the essence of our constitutional structure. The march for the Tolpuddle martyrs, the meeting at Congregational Memorial Hall to overturn Taff V ale and organise the Labour Party, the fight of the Suffragettes, the Notting Hill riots and the first carnivals, the Dagenham strike for equal pay, were all moments of constitutional significance, producing lasting constitutional reform. ${ }^{90}$

\footnotetext{
86 See H Collins, KD Ewing and A McColgan, Labour Law: Text, Cases and Materials (CUP 2012) and E McGaughey, A Casebook on Labour Law (2018)

87 Gisda Cyf v Barratt [2010] UKSC 41, [37]

88 See P Davies and M Freedland, Labour Legislation and Public Policy (1993)

89 S Webb and B Webb, Industrial Democracy (1920) Part III, chs III(b) and (e).

90 Though driven by the labour movement, they are as important as Peel's repeal of the Corn Laws, as Disraeli's piloting of the Second Reform Act 1867, as Baldwin's piloting of the Representation of the People (Equal Franchise) Act 1928, or as Thatcher's support for the Equal Pay Act 1970. See E McGaughey, A Casebook on Labour Law (2018) ch 1(3)(c).
} 
Second, companies are essential to economic life, and structured by the Companies Act 2006, the Insolvency Act 1986, and the Financial Services and Markets Act 2000. As explained above, the South Sea Bubble of 1720 transformed the British constitution, and also directly resulted in statute and case law on the accountability of fiduciaries in a governance structure, ${ }^{91}$ their being bound by law, and their duty to avoid any possibility of conflicts of interest, which run through corporate regulation today. ${ }^{92}$ The constitutional functions of these principles (to say nothing about the East India Company ${ }^{93}$ ) are also illustrated in the development of insolvency law. It is often forgotten that this was the single most important legislative issue in the $19^{\text {th }}$ century. ${ }^{94}$ Charles Dickens immortalised the problems of debtors' prison through his writing, ${ }^{5}$ the period where the Joint Stock Companies Winding-Up Act 1844, the Limited Liability Act 1855, and the Joint-Stock Companies Act 1856 were passed. ${ }^{96}$ Together these enabled social protection from insolvency, establishing principles of fair, transparent, and accountable winding up procedures. ${ }^{97}$ Similarly after successive crises, and by understanding the Wall Street Crash in the US, financial regulation follows principles of transparency, prudence, and preventing conflicts in all securities markets. ${ }^{98}$ These are essential to protect the financial integrity of the state, and to guarantee the right to social security, through occupational retirement schemes invested in the stock markets. ${ }^{99}$

Third, the market segment of the economy, the base for VAT and an array of duties and levies, derives from the laws of obligations and property, heavily codified through the Sale of Goods Act 1979, the Competition Act 1998, and the Consumer Rights Act 2015. These Acts recast principles from the Sale of Goods Act 1893, the Monopolies and Restrictive Practices (Inquiry and Control) Act 1948, and the Unfair Contract Terms Act 1977. They require that people have a right to run their business, and to do so according to the principle of fair competition, while guaranteeing consumers a high level of protection against unfair practices. A wealth of sector-specific legislation in markets which systematically fail - such as transport, electricity - also ensures that prices are fair, that universal service is provided, and that basic standards of service are adhered to. ${ }^{100}$

Fourth, land is the tax base for business rates and council tax, while the protection of the environment is the growing base for taxes like the climate change levy, landfill tax, petroleum revenue tax, air passenger duty, and vehicle excise. For land ownership, major statutes include the Land Registration

\footnotetext{
Bubble Act 1720 prohibited incorporation without Parliament, while Attorney General v Davy (1741) 26 ER 531 set the default rule to require that $50 \%$ plus one in the general meeting could do any corporate act, and thus exercise constitutional control.

92 Keech v Sandford (1726) 25 ER 223, Lord King LC, and see today the Companies Act 2006 ss 175-177. Lord King LC was deliberately chosen to replace Lord Macclesfield LC, who before his disgrace over his role on the South Sea Company, decided in Bromfield $v$ Wytherley (1718) Prec Ch 505 that a fiduciary was entitled to take money from a trust, invest it on their own behalf, and keep the profit, if they restored money to the trust. Macclesfield was impeached in the House of Lords, tried and found guilty of taking bribes in 1725 .

93 See S Tharoor, Inglorious Empire (2018)

94 See M Lester, Victorian Insolvency (Clarendon 1995)

5 C Dickens, David Copperfield (1850), Hard Times (1854) and Little Dorrit (1857)

6 The Debtors Act 1869 finally abolished imprisonment for debt.

See further V Finch and D Milman, Corporate Insolvency Law: Principles and Perspectives (2017)

98 Generally, N Moloney, E Ferran and J Payne (eds), Oxford Handbook of Financial Regulation (2017) ch 1.

99 See E McGaughey, Participation in Corporate Governance (2014) ch 6 and E McGaughey, 'Democracy in America at work: the history of labor's vote in corporate governance' (2019) 42 Seattle University Law Review 697, part II.B.

100 e.g. Electricity Act 1989, Water Industry Act 1991, Railways Act 1993, Communications Act 2003, etc
} 
Act 2002, the Compulsory Purchase Act 1965, the Town and Country Planning Act 1990. Dating back to the Land Registration Act 1925, and the Town and Country Planning Act 1947, these enshrined (even if incomplete) the principles of transparency of land ownership, and that property carries responsibility to neighbours and the community. For the environment, the Environmental Protection Act 1990 and the Climate Change Act 2008 confront existential problems as scientific understanding has developed since the 1980s. They update what were the Public Health Acts of the $19^{\text {th }}$ century and the Clean Air Acts in the post-war era. They put into practice the right to a clean environment.

While these categories of constitutional principle may appear tangential to narratives presented in some constitutional and public law books, they are central commitments made by the UK in international law, particularly the International Covenant on Economic, Social and Cultural Rights $1966 .{ }^{101}$ This treaty, signed and ratified by 169 countries, recodified the Universal Declaration on Human Rights, the 'international Magna Carta' of humanity, ${ }^{102}$ and binds the UK. Nearly all institutions summarised, and the rights that developed from them are also in the constitutions of other democratic European and Commonwealth countries, particularly the right to take collective action, ${ }^{103}$ to run a business, ${ }^{104}$ to consumer protection, ${ }^{105}$ that property carries responsibility, ${ }^{106}$ and the right to a clean environment. ${ }^{107}$ It is true that fewer constitutions and human rights charters explicitly give space for fair competition, ${ }^{108}$ or corporate and financial accountability, albeit that a growing discussion in international law is calling for business to be infused with human rights. Corporate and financial accountability is, however, an established part of the tradition of UK law, and fundamental to its constitutional development. In this way, it is also possible for the UK to be, not just a follower, but at the forefront of constitutional law and human rights.

\section{(3) Principles in CASE LAW}

A third main source of evidence about the nature of the UK's true constitution is the case law of the judiciary. The HS 2 decision recognised this, as the Supreme Court stated that 'common law itself also recognises certain principles as fundamental to the rule of law. ${ }^{109}$ On the one hand, these principles could include the right against unjust discrimination, ${ }^{110}$ the right against unfair competition and to take collective action, ${ }^{111}$ or the right against environmental damage. ${ }^{112}$ As well as common law, equity recognises fiduciary

\footnotetext{
101 International Covenant on Economic, Social and Cultural Rights 1966 arts 6-15

102 E Roosevelt, On the Adoption of the Universal Declaration of Human Rights (9 December 1948)

103 e.g. Charter of Fundamental Rights of the EU $2000 \underline{\operatorname{art} 28}$

104 e.g. Grundgesetz art 12

e.g. CFREU art 38

106 e.g. Grundgesetz art 14(2) dating back to the Weimar Constitution 1919 art 153(3)

107 e.g. CFREU art 37

108 cf FD Roosevelt, 'Eleventh State of the Union Address' (1944) on a Second Bill of Rights

109 R (HS2 Action Alliance Ltd) v Secretary of State for Transport [2014] UKSC 3, [207]

110 e.g. Kruse v Johnson [1898] 2 QB 91 and Constantine v Imperial Hotels Ltd [1944] KB 693

111 e.g. Mogul Steamship Co Ltd v McGregor, Gow \& Co [1892] AC 25, Crofter Hand Woven Harris Tweed v Veitch [1942] AC 435 and cf OBG Ltd v Allan [2007] UKHL 21, [56].

112 e.g. Rylands v Fletcher (1866) LR 1 Ex 265 and most recently Lungowe v Vedanta Resources plc [2019] UKSC 20.
} 
duties against conflicts of interest, ${ }^{113}$ that property carries responsibility, ${ }^{114}$ and the right against unjust dismissal. ${ }^{115}$ But as anyone familiar with these lines of cases knows, such rights at common law and equity are, and can always be contested, qualified, refined or reversed. This is in the nature of case law. Any list, moreover, could be very long. On the other hand, case law recognises certain basic principles, which function at a higher level than other constitutional norms, either of structure, procedure, or rights, because they go to the mechanisms of construction. Four central principles can be identified.

First, our courts recognise the principle of representative, and deliberative democracy. While the path toward democracy was long, ${ }^{116}$ and anything but inevitable, the principle of a democratic society pervades the legal system, and is the central legitimating factor in the sovereignty of Parliament. This is seen, first, in the construction of legislation relating to political spending. The Magna Carta in 1215 proclaimed: 'To no one will we sell, to no one will we refuse or delay, right or justice'. Similarly, in the Animal Defenders case, Baroness Hale in 2008 stated that in the UK and Europe 'we do not want our government or its policies to be decided by the highest spenders. Our democracy is based upon more than one person one vote. It is based on the view that each person has equal value. ${ }^{117}$ Second, it is seen in connection with the general principle, expressed in the Simms case, that 'Parliament must squarely confront what it is doing and accept the political cost. Fundamental rights cannot be overridden by general words', so as to prevent incursions passing 'unnoticed in the democratic process. ${ }^{.118}$ Thus this principle forces greater deliberation in representative government. It opposes irrational executive action. ${ }^{119}$ The democratic principle certainly does not include referendums, which in the UK context appear to frustrate the good administration of government. ${ }^{120}$ By contrast deliberative, representative democracy must now be regarded as a norm whose weakening, let alone undoing, is unthinkable. 'Freedom once given cannot be taken away. ${ }^{121}$

Second, the judiciary recognises the rule of law as an overriding constitutional norm. The rule of

$\overline{113}$ e.g. Keech v Sandford (1726) 25 ER 223, noted above.

114 Summed up in the maxims sic utere tuo ut alienum non laedas (use of property should not harm) See Wright v Simpson (1802) 31 ER 1272, 1275. Also at common law, ubi emolumentum, ibi onus (where the benefits lie, so should the burdens): Turberville v Stampe (1697) 91 ER 1072, per Holt CJ, '... it being for the master's benefit.'

115 e.g. Dean $v$ Bennett (1870) LR 6 Ch 489 (finding in equity that a dismissal was unjust) and Wilson v Racher [1974] ICR 428 (holding that there is a common law duty of mutual respect, precluding wrongful dismissal at common law).

116 The point at which the UK could claim to be a democracy was probably only with the Representation of the People (Equal Franchise) Act 1928, and even then such a point ignores the subjugation of political freedom in the Empire. On this view, when all of Her Majesty's citizens had the right to vote (with only limited exceptions, such as for prisoners), the UK was not democratic until the waves of independence in the late 1960s and 1970s. The disintegration of Empire therefore coincides with the UK's entry into the European Economic Community. There was never a point at which the UK was an 'independent', unconnected nation: see T Snyder (1 July 2016) Ukravinska Pravda, 'there never was a moment when Great Britain was alone. It was an empire, and then it integrated into Europe.'

117 R (Animal Defenders International) v Secretary of State for Culture, Media and Sport [2008] UKHL 15, [48]. See also R v Jones [1999] 2 Cr App R 253, 255, per Lord Bingham CJ stating there is a need 'to achieve a level financial playing field between competing candidates, so as to prevent perversion of the voters' democratic choice between competing candidates within constituencies by significant disparities of local expenditure.'

118 R (Simms) v SS for the Home Department [1999] UKHL 33, [2000] 2 AC 115, 131, per Lord Hoffmann

119 Arguably R (Miller) v Secretary of State for Exiting the European Union [2017] UKSC 5 was an example of this.

${ }^{120}$ See further E McGaughey, 'Could Brexit be void?' (2018) 29(3) King’s Law Journal 331, but contrast Wilson v PM [2019] EWCA Civ 304. It seems likely that this judgment is far from the final word: contrast the Swiss Federal Court 'Heiratssrafe' (or Marriage Penalty) case of 10 April 2019, declaring a referendum invalid based on misrepresentation. The ex tempore judgment available at bundesgericht.simplex.tv, pending written reasons.

121 Blackburn v AG [1971] EWCA Civ 7, per Lord Denning MR 
law was said by Lord Bridge to be 'as important in a free society as the democratic franchise'. ${ }^{122}$ It applies to 'all persons and authorities within the state, whether public or private'. ${ }^{123}$ In $R$ (Unison) $v$ Lord Chancellor this meant that fees for employment tribunals had to be regarded as ultra vires, Lord Reed stating that the 'constitutional right of access to the courts is inherent in the rule of law'. In this way, like other principles of construction, multiple rights can be developed by the courts out of the overriding norm.

Third, the UK's social welfare state is a general principle, used to construe both common law and statute. In Gorringe v Calderdale MBC, Lord Steyn said it was 'necessary' to view the law of negligence in the context of 'the contours of our social welfare state, ${ }^{124}$ a necessity that can be observed across the law of obligations, property and through statute. In the landmark decision of Gisda Cyf v Barratt, Lord Kerr went as far as to say that the 'need to segregate intellectually common law principles relating to contract law, even in the field of employment, from statutorily conferred rights is fundamental'. ${ }^{125}$ This meant, a standard rule of contract law that one is bound by a notice when one may reasonably be deemed to have seen it - not when one actually sees it - did not apply to an employment contract's termination. This meant that the three month time limit for the employee to claim unfair dismissal only began once she actually knew she had been dismissed, not when a letter arrived at an empty home. Thus social principles, consistent with statutory rights, transform the nature of the common law. There is a fusion at work. As a principle of construction, statute and case law are read as a whole, in their context, to reflect the background of social expectations. ${ }^{126}$

Fourth, the principle of international comity transcends all common law and statute. In $R v$ Lyons, Lord Hoffmann stated that 'there is a strong presumption in favour of interpreting English law (whether common law or statute) in a way which does not place the United Kingdom in breach of an international obligation. ${ }^{127}$ Similarly the Court of Appeal stated it 'is a principle of legal policy that the municipal law should conform to public international law. ${ }^{128}$ Again, this principle functions through construction, so that Parliament 'cannot be supposed merely by reason of its having used general words to be intending to do that which is against the comity of nations'. ${ }^{129}$ For example in Hounga v Allen, the common law defence

$122 X v$ Morgan-Grampian Ltd [1991] AC 1, 48, per Lord Bridge, 'The maintenance of the rule of law is in every way as important in a free society as the democratic franchise. In our society the rule of law rests upon twin foundations: the sovereignty of the Queen in Parliament in making the law and the sovereignty of the Queen's courts in interpreting and applying the law.'

${ }^{123}$ T Bingham, Rule of Law (2008) 8, 'all persons and authorities within the state, whether public or private should be bound by and entitled to the benefit of laws publicly made, taking effect (generally) in the future and publicly administered in the courts.'

124 Gorringe v Calderdale MBC [2004] UKHL 15

125 Gisda Cyf v Barratt [2010] UKSC 41, [39]

126 See further, Johnson v Unisys Ltd [2001] UKHL 13, [35]-[37] per Lord Hoffmann, and noting how 'statute and common law have proceeded hand in hand.'

${ }^{127} \mathrm{R} v$ Lyons [2003] 1 AC 976, [27]. He goes on to say 'As Lord Goff of Chieveley said in Attorney-General v Guardian Newspapers Ltd (No 2) [1990] 1 AC 109, 283: 'I conceive it to be my duty, when I am free to do so, to interpret the law in accordance with the obligations of the Crown under [the Convention]'?

128 Saad v SS for the Home Department [2001] EWCA Civ 2008, [15] Lord Phillips MR, quoting FAR Bennion, Statutory Interpretation ( $3^{\text {rd }}$ edn 1997) 630. cf R (SG) v SS for Work and Pensions [2015] UKSC 16, [247]-[257] per Lord Kerr, advocating adopting monism.

129 Colquboun v Brooks (1888) 21 QBD 52, 57-58 per Lord Escher MR, and see also Smith v East Elloe District Council [1956] AC 736, 765, per Lord Reid, 'There are many cases where general words in a statute are given a limited meaning...they are limited so as not to conflict with international law'. 
of illegality had to be construed in the light of the UN Convention against Transnational Organised Crime, 2000. ${ }^{130}$ This resulted in enabling a young, undocumented migrant to claim race discrimination (and probably also to have succeeded in a wage deduction claim ${ }^{131}$ ) notwithstanding the fact that she had violated the Immigration Act 1971 by arriving to work in the UK. This is because international law requires that the victims of traffickers are protected from employers, not the other way around. Also dramatically, in FHR European Ventures LLP v Cedar Capital Partners LLC the Supreme Court held that profits resulting from a trustee's breach of fiduciary duty were held on constructive trust, and so elevated in insolvency priorities above secured creditors, despite fiduciary duties often being conceptualised as part of the law of obligations. This reversed long-standing common law precedent, and one of Lord Neuberger's own recent judgments, ${ }^{132}$ because the Supreme Court took into account the UN Convention against Corruption 2003. ${ }^{133}$ While the UK is yet to develop a full 'monist' system, it nevertheless has a powerful commitment in its principles of construction to ensure that the UK abides by international law. ${ }^{134}$

Together these four principles of construction - of democracy, the rule of law, the social state, and international comity - are so basic that they can be seen to pervade the interpretation of all statute and case law. They are usually unwritten assumptions, because ultimately they derive from a deep-seated consensus about the building blocks of a just society. They are maintained by the force of social opinion. ${ }^{135}$ Of course, while social opinion can remain remarkably consistent and unmoved over time, it is possible to degrade it through concerted political action, and by attacking civil society and its institutions. This is why constitutional principles should be openly recognised, and defended, to ensure that they are an irremovable part of the UK constitution. ${ }^{136}$ In this sense, it may be regarded as correct to say that judicial principles of construction are 'the ultimate controlling factor[s] on which our constitution is based. ${ }^{137}$

\section{CONCLUSION}

What is the UK's true constitution? The answer must be that the true constitution is democratic, social, and principled. By looking at what the UK government actually does, the way that the state is constituted, it must be recognised that essential components of our constitution include the right to social security, a universal, free and equal health system, free universal education, a right to social inclusion, fair taxation, protection for the environment and countryside, fair wages through voice at work, and transparent and accountable governance of finance and enterprise, at the least. The list is not closed. In the operation of

[2014] UKSC 47

31 See Patel v Mirza [2016] UKSC 42, [63]-[66] per Lord Sumption

132 Sinclair Investments (UK) Ltd v Versailles Trade Finance Ltd [2011] EWCA Civ 347

133 [2014] UKSC 45, [42] alongside the OECD Convention on Combating Bribery of Foreign Public Officials in International Business Transactions 1999 and the Bribery Act 2010.

134 This may be termed the 'indirect effect' of international law.

135 JS Mill, On Liberty (1859) ch 2, on the force of social opinion, and HLA Hart, The Concept of Law (2 $2^{\text {nd }}$ edn 1994) 56-57.

136 See Y Roznai, Unconstitutional Constitutional Amendments: The Limits of Amendment Powers (2019)

137 R (Jackson) v Attorney General [2005] UKHL 56, [104] per Lord Hope. While the 'rule of law' may be argued, as Lord Hope suggested, to rank above Parliamentary sovereignty, it is harder to justify placing the rule of law above representative democracy. In truth, both are so heavily interconnected that it makes no sense to try awarding a first or second place. 
law, our courts have consistently recognised core principles of construction, that must be regarded as indelible components of our constitution: the principles of democracy, the rule of law, the social welfare state, and international comity. So long as the judiciary exists, it would be unthinkable and maybe impossible to degrade or erase them through any act of the executive, or any Act of Parliament. ${ }^{138}$

What must be clear is that any theory about what the UK's uncodified constitution 'is', not what we think it 'ought to be', must make its case with an appeal to evidence, and through reasoned argument. The oldest traditions of UK constitutional thought, from Blackstone or Maitland, and in modern contributions of Griffith or Ewing, adopt the preferable view that a constitution cannot be shackled within a public/private divide. History and society are not so compliant, and constantly remind us that the way we may organise our court procedures, ${ }^{139}$ or may want to organise law school curricula, ${ }^{140}$ for reasons of convenience, cannot determine our conceptions of constitutional law. Of course, law is not a natural science, where facts and causation in the physical word exist regardless of people's opinions. In the humanities, social sciences, and law, the force of people's opinions, the foundations of overlapping consensus, do create the reality being observed. A clear distinction between what 'is' and what 'ought to be' in law is conceptually impossible, if not absurd, ${ }^{141}$ because the way we describe and explain the law contributes to shaping its very reality. Law, like all social institutions, like all of humanity's beliefs and conflicts, begins in the minds of women and men, and so it is in the mind that the foundations of justice must be constructed. ${ }^{142}$ This is why it is important in matters of interpretation not easily to concede, and sometimes not at all, that the law 'is' what it is, even if it produces injustice. The UK's true constitution is just.

\footnotetext{
138 n.b. Plainly an Act of Parliament is the highest norm in our constitution, and overrides all other sources of law. I have not, however, heard any credible argument that an Act of Parliament could abolish the courts, or restrict their independence. In a serious political crisis, of course, institutions are taken over through fear, coercion and then force, and depend upon a mass social movement for their defence, not merely the courts: see O Kahn-Freund, 'Autobiographical Memories of the Weimar Republic: A Conversation with Wolfgang Luthardt' (February 1978) original in (1981) 14(2) Kritische Justiz 183, translated into English by E McGaughey (2016) KCL Law School RP No. 2016-34.

139 e.g. O'Reilly v Mackman [1983] 2 AC 237, 255, per Lord Denning MR, on a private/public divide for judicial review time limits.

140 e.g. P Birks, 'Before we begin: five keys to land law' in S Bright and J Dewar, Land Law: Themes and Perspectives (1998) 457, 459, distinguishing between 'contextual' subjects like land law, and 'conceptual' subjects like those flowing from the public/private divide. See further, E McGaughey, A Casebook on Labour Law (2019) Preface.

141 See Q Skinner, Visions of Politics (2002) vol 1, ch 2, and L Wittgenstein, Philosopbical Investigations (1953) \$\$23, 43 and 199-203.

142 cf United Nations Educational, Scientific and Cultural Organization Constitution 1946, preamble, 'That since wars begin in the minds of men, it is in the minds of men that the defences of peace must be constructed'.
} 